\title{
Avaliação do Nível de Genotoxicidade através do Ensaio Cometa em Manipuladores de Quimioterápicos em Serviços de Oncologia
}

\author{
Fernanda Rombaldi', Carina Cassini ${ }^{2}$, Luciana Garlet Pesamosca ${ }^{3}$, Mirian Salvador ${ }^{4}$, Jenifer Saffi ${ }^{5}$, Bernardo Erdtmann ${ }^{6}$
}

Introdução: é crescente a preocupação sobre o efeito mutagênico e carcinogênico de agentes genotóxicos em populaçôes expostas ocupacionalmente. Entre os diferentes agentes de risco ocupacional, destacam-se as drogas antineoplásicas. Objetivo: este trabalho avaliou o risco ocupacional dos profissionais que manipulam quimioterápicos em hospitais e clínicas de Caxias do Sul (RS), Brasil. Metodologia: vinte farmacêuticos e enfermeiros que manipulam quimioterápicos foram monitorados durante uma semana de trabalho, tendo sido coletadas seis amostras de sangue: segunda-feira pela manhã (antes de iniciar o trabalho) e à tarde, e terça a sexta-feira à tarde. Foi avaliada a genotoxicidade, através do ensaio cometa que identifica dano ao DNA; e, por ser simples, rápido e de baixo custo, tem sido recomendado para avaliação rotineira de trabalhadores em risco com agentes genotóxicos. Resultados: neste trabalho, os indivíduos expostos apresentaram um aumento no dano ao DNA pelo teste cometa em relação aos controles em todas as amostras, exceto na segunda-feira de manhã ( $\mathrm{p}=0,000$ e $\mathrm{p}=0,143$, respectivamente), mostrando assim a importância do descanso do final de semana. Os resultados do ensaio cometa também mostraram uma correlação positiva com os dias da semana e com o consumo de álcool ( $r=0,228, p=0,014)$. Conclusão: o monitoramento de profissionais em risco ocupacional de forma mais prolongada, como neste estudo, durante uma semana, é extremamente relevante, pois pode apresentar novos aspectos do comportamento de risco, cujos resultados podem complementar o controle do risco de genotoxicidade.

\footnotetext{
${ }^{1}$ Farmacêutica, Mestre em Biotecnologia pela Universidade de Caxias do Sul (UCS)

${ }^{2}$ Farmacêutica, Mestranda em Biotecnologia pela UCS

${ }^{3}$ Enfermeira, Especialista em Saúde Pública

${ }^{4}$ Farmacêutica, Profa. Dra. Titular do Programa de Pós-Graduação em Biotecnologia - Instituto de Biotecnologia, UCS

${ }^{5}$ Farmacêutica, Profa. Dra. Titular do Laboratório de Genética Toxicológica/Curso de Farmácia da Universidade Luterana do Brasil, Canoas (RS)

${ }^{6}$ Biólogo, Prof. Dr. Titular do Programa de Pós-Graduação em Biotecnologia - Instituto de Biotecnologia, UCS

Endereço para correspondência: Fernanda Rombaldi. Rua Pinheiro Machado, 2.569 - Sala 31 - Bairro São Pelegrino - CEP: $95020-170$ - Caxias

do Sul (RS), Brasil. E-mail: fernanda@cecanrs.com.br
} 